\section{Madrid (Spain).}

D.M. Freire-Lista ${ }^{(1,2)}$ and R. Fort ${ }^{(1,2)}$

(1) Instituto de Geociencias IGEO (CSIC, UCM) Spanish Research Council CSIC - Complutense University of Madrid UCM. Madrid, Spain (d.freire@igeo.ucm-csic.es, rafort@csic.es) Phone: +34 913944903

(2) CEI Campus Moncloa, UCM-UPM and CSIC, Madrid, Spain

Masons have traditionally used granite anisotropy to cut and lay the stone. Scaling, a common type of granite decay, is observed worldwide.

This study explored the relationship between weathering and cut planes in heritage ashlars, specifically in the stone on Madrid's Plaza Mayor, whose construction dates back to 1590 . The 71 rectangular granite columns that support its porticoes are oriented toward the four cardinal points. All 71 have one exposed side that faces the square, one protected side facing inward and two semi-protected sides perpendicular to the other two. The sides of the columns are also oriented to the points of the compass.

This study aimed to identify the prevailing orientation of scaling, if any, in the granite ashlars and to determine how this process is affected by climate, microclimate (orientation), use, hewing and exfoliation microcracks.

All four sides of the 71 columns were mapped (284 in all) to analyse scaling height, distribution and orientation. The findings showed that the microcracks are vertically oriented and decline in density and length with depth from the surface. Scaling was observed on the lower ashlars in the columns to a maximum depth of $3 \mathrm{~mm}$.

Determining the direction of exfoliation microcracks is imperative to understanding decay mechanisms in granite ashlars and sculptures and that information must be taken into consideration when applying conservation treatments.

Keywords: decay, granite, exfoliation microcracks, bush-hammering. 


\section{1- Introduction}

Construction granite decays under the independent action of intrinsic and extrinsic factors. Intrinsic factors, attributable to the geological history of the pluton from which granite is quarried, determine its mineralogical composition and texture, including crystal size, shape and borders; chemical composition; porosity (Jeannette, 1997; Weiss et al., 2000; Přikryl, 2001; Sousa, 2013); density; anisotropy (Pérez-Ortiz et al., 1996; Takemura et al., 2003; Lin and Takahashi, 2008; Fort et al., 2011); ultrasound propagation velocity (Prrikryl et al., 2003; Martínez-Martínez, 2006); mechanical strength (Gupta and Seshagiri Rao, 1998; Eberhardt et al., 1999; Benavente et al., 2004; Vasconcelos et al., 2007; Nováková, et al., 2011); roughness (Alonso et al., 2007; López-Arce et al., 2010); and permeability (Moses et al., 2014). Hence, the microcracks intrinsic to granite ashlars are the result of natural processes affecting the pluton, such as tectonics (Laubach et al., 2004; Anders et al., 2014), exhumation (Nadan and Engelder, 2009; Benkó et al., 2014) and decompression (Holzhausen et al., 1989; Bahat et al., 1999; Ziegler et al., 2013, 2014).

Environmental, architectural, social and economic factors (Turkington, 2002), as well as usage and construction practice, are among the extrinsic causes of granite decay. Anthropogenic decay includes all manner of human activity: quarrying, handling/laying, application of conservation treatments (Alcalde Moreno and Villegas, 2003; Varas-Muriel et al., 2015), use of indoor heating (Varas-Muriel et al., 2014), emission of pollutants (Grossi et al., 1998; Schiavon et al., 2000; Brimblecombe, 2003; Simão et al., 2006; Brimblecombe and Sturges, 2009); as well as vandalism (Rivas et al., 2012) and war (Siegesmund et al., 2002).

To be used in construction, quarried stone blocks must be readily split, pitched, hewn and polished. As granite is not easily hewn, traditional quarrymen used its slip planes to improve its workability. Their terms for splitting directions are rift, grain and hard-way or cut-off (in decreasing order of splittability). The rift plane is the plane traditionally preferred for hewing and subsequent use as the outer surface on ashlars in heritage buildings. In this paper, once so 
worked, that plane is referred to as the 'cleft' plane, to paraphrase Shadmon (1989). Traditional stone quarrying, cutting, dimensioning and hewing generate microcracks.

Microcracks condition granite decay (Åkesson et al., 2004; Esbert, 2007; Lindqvist et al., 2007a, b; Sousa, 2010; Freire-Lista, 2015a) and favour the action of external agents (Benavente et al., 2008), as they constitute the gateway for the inflow and outflow of water circulating across the stone (Vandevoorde, 2009; Ruiz de Argandona, 2009; Vázquez et al., 2015). Their orientation and connectivity are consequently of cardinal importance (Hoffmann and Niesel, 1992; Camuffo, 1998). Water is more aggressive in the presence of salts (Rodríguez-Navarro et al., 2000; Chabas and Jeannette, 2001; Török and Rozgonyi, 2004; Alonso et al., 2008; Vázquez-Menéndez et al., 2008; López-Arce et al., 2010, 2011; Yu and Oguchi, 2010).

The most prominent physical mechanisms that cause decay are changes in pressure (structural fatigue) or ambient temperature (Camuffo, 1995; Andrés de Pablo and Palacios, 2004; Hall and Thorn, 2014), thermal shock (Lin, 2002) and freeze/thaw events (Freire-Lista et al., 2015a). Pressure change is associated with ice or salt crystallisation in the voids in granite and the distribution of stress on the structure (Hor and Morihiro, 1998; Coussy and Fen-Chong, 2005; López Arce et al., 2010; Hamdi, 2011; Hamdi and Lafhaj, 2013). Variations in temperature induced by solar radiation (Gómez-Heras et al., 2006; Erguler, 2009; Erguler and Shakoor, 2009), fire (Gómez- Heras et al., 2008, 2009) or artificial sources of heat are related to the differences in the expansion coefficient of the constituent minerals in the stone, which translate into decay in the form of cracking (Hall, 1999; Koch and Siegesmund, 2004; Takarli and Prince-Agbodjan., 2008; Hamdi et al., 2008; Takarli et al., 2014).

Generally speaking, granite is highly durable (Le Pera and Sorriso-Valvo, 2000; Matías and Alves, 2002; Siegesmund and Török, 2011), very hard and scantly sorptive. Decay is nonetheless a natural, uncontrollable and inevitable process due to the metastable conditions prevailing on granite surfaces, the result of the differences between atmospheric conditions and the high temperature and pressure prevailing at the depths at which the stone forms. In 
1

2

3

4

5

6

7

8

9

aggressive conditions, feldspars are the minerals most vulnerable to chemical decay (Sinha et al., 2010; Catlos et al., 2011; Freire-Lista et al., 2015b), whereby they are transformed into clayey materials (Wilson, 2004; Upadhyay, 2012). That clayey mineralogy diminishes durability and hardness and raises sorptivity. Obvious differences in durability can be detected, then, between granite with healthy and stone with altered feldspars (Alves et al., 1996; Sousa and Gonçalves, 2013).

The agents of decay that prevail in a given site need to be determined (Begonha and Braga, 2002; Hall et al., 2012). The position of granite on a structure is very important, for the effect on floors differs widely from the impact on indoor walls or façades (García-del-Cura et al., 2008; Pires et al., 2014; Siegesmund and Snethlage, 2014); ashlars nearest the ground are most highly exposed to aggressive agents and hence most vulnerable to decay. Scaling, a very common form of decay in granite ashlars, affects monuments the world over (Bromblet et al., 1996; Zhang et al., 2010; Jo and Lee, 2014).

The present study aims to assess the effects of intrinsic (exhumation-induced) microcracking, as well as extrinsic factors such as quarrying, hewing, and environmental conditions on granite scaling.

The microscopic exploration of the microcracks attributable to bush-hammering and found at different depths and orientations in granite ashlars will help understand the causes of decay on heritage structures.

\section{Materials and methods}

An emblematic Spanish monument built with Piedra Berroqueña (Freire-Lista and Fort, 2015c) was chosen for this study: Madrid's Plaza Mayor [main square]. Built between 1590 and 1619, it underwent refurbishing after each of three fires that blazed in 1631, 1670 and 1790 (Figure 1A). After the 1790 reconstruction, the square acquired its present rectangular shape $(129 \times 94$ metres $)$ in which the large granite porticos that enclose it on all four sides were maintained or rebuilt as necessary. The 71 orthohedral granite columns that constitute the inner 
1 perimeter of the square are distributed as follows: 16 each on the north and south porticos, and

218 on the east and 21 on the west porticos (Figure 2A). The columns are unengaged on all four sides (Figure 2B).
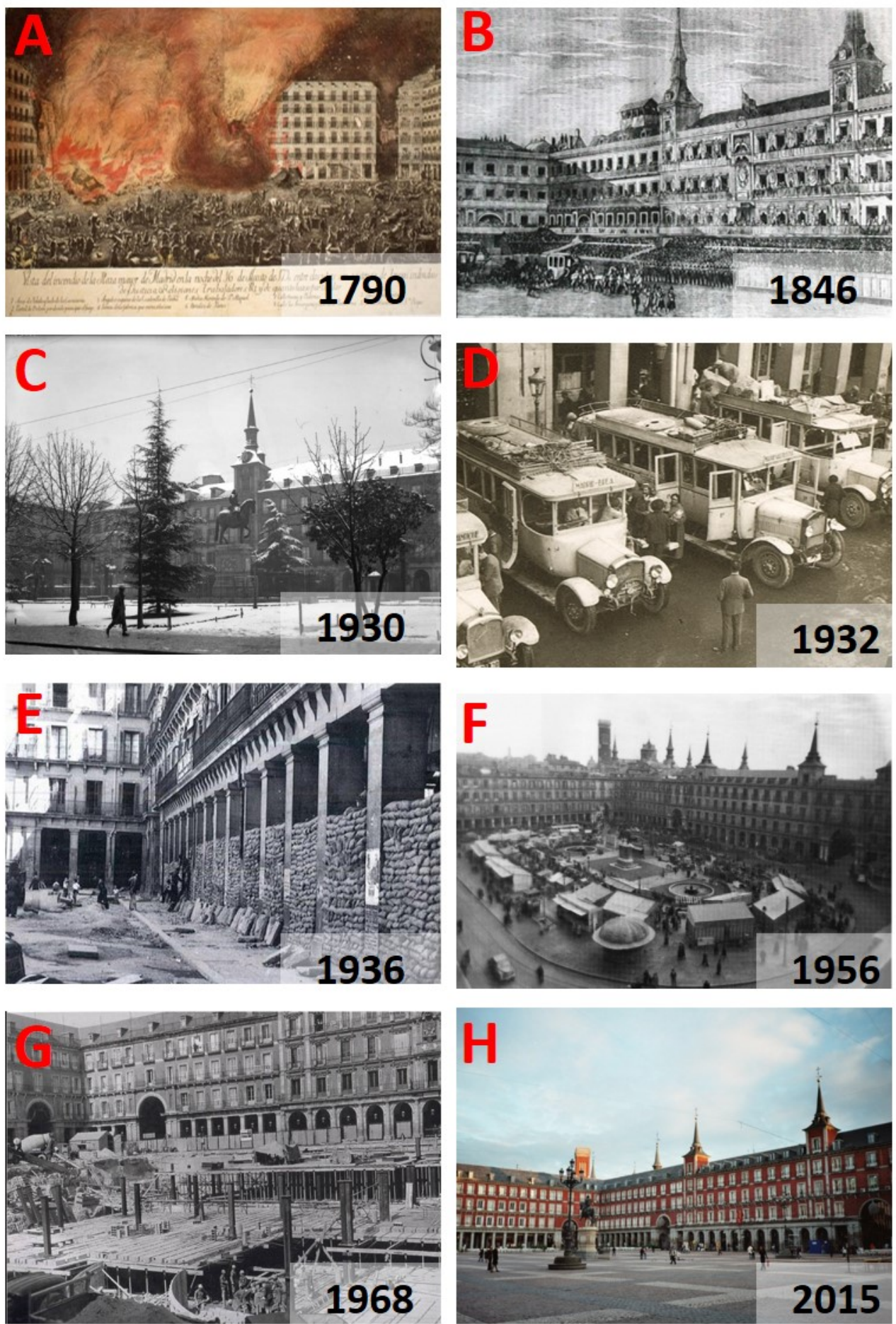

4

Figure 1. A: engraving of the 1790 fire; B: engraving of a bull fight in the square, 1846; C: after a snowstorm, 1930; D: bus stop, 1932; E: during the Spanish Civil War, 1936; F: open-air market, 1956; G: construction of underground car park, 1968; H: the square in 2015. 
1 These columns have an $80 \times 95 \mathrm{~cm}$ rectangular base and vary in height with ground elevation.

2 The shafts comprise three orthohedral ashlars $70 \mathrm{~cm}$ wide (on the side facing the square), $82 \mathrm{~cm}$

3 deep and $120 \mathrm{~cm}$ high. The area is consequently smaller on the sides facing the square and the

4 inner gallery. The capitals consist of neck, echinus and abacus (Figure 2C)

5 Detachment in the form of blistering (irregular raising of a thin, air-filled layer of surface stone)

6 or scaling (peeling away of the surface or near-surface layer of stone) is the most common type

7 of decay on Madrid's Plaza Mayor (Figures 2E, 2F and 2G). Sub-categories of scaling include

8 flaking (detachment of a uniform, sub-millimetric to millimetric layer of stone) and contour

9 scaling (in which the interface with the healthy stone is parallel to the stone surface). Contour scaling on flat surfaces may be called spalling.

The bottom ashlars in the 71 orthohedral column shafts on Madrid's Plaza Mayor (Figures 2B, 2C and 2D) were mapped to determine scaling orientation and height-wise distribution as well as the percentage of the area affected. Mapping was conducted in situ on a total of 284 photographs (four sides of 71 columns). The decay mapping results were processed with UTHSCSA ImageTool 3.0 software to calculate the area of the ashlars affected by scaling. The bottom ashlars were chosen because while not significantly decayed, they exhibited the the most intense scaling.

Thin sections parallel and perpendicular to the cleft plane were taken from a sample removed from column 36 .

Thin sections were cut from the remains of a staircase step made of a traditionally hewn subtype of Piedra Berroqueña granite quarried at Alpedrete in the province of Madrid $\left(40^{\circ} 39^{\prime} 45.7^{\prime \prime} \mathrm{N} 4^{\circ} 00^{\prime} 47.7^{\prime \prime} \mathrm{W}\right)$. This stone is a medium-grained, hypidiomorphic, equigranular monzogranite with $5.8 \%$ total anisotropy, bulk density of $2669 \pm 17 \mathrm{~kg} / \mathrm{cm}^{3}$ and $0.8 \pm 0.1 \%$ effective porosity (Fort et al., 2013), and a Global Heritage Stone Recourse listing (Freire-Lista et al., 2015d). The step was hewn along the cut lines of the stone (Figure 3). The cleft was used for the tread or horizontal plane of the step, the grain for the riser or vertical plane and hard-way for the plane perpendicular to both, with the smallest area. Further to traditional Madrilenian 
3 quarrying practice, the stone was bush-hammered in a three-stage process: first with a

$4 \quad 5 \times 5$-tooth, then with a $7 \times 7$-tooth and lastly with an $11 \times 11$-tooth hammer.
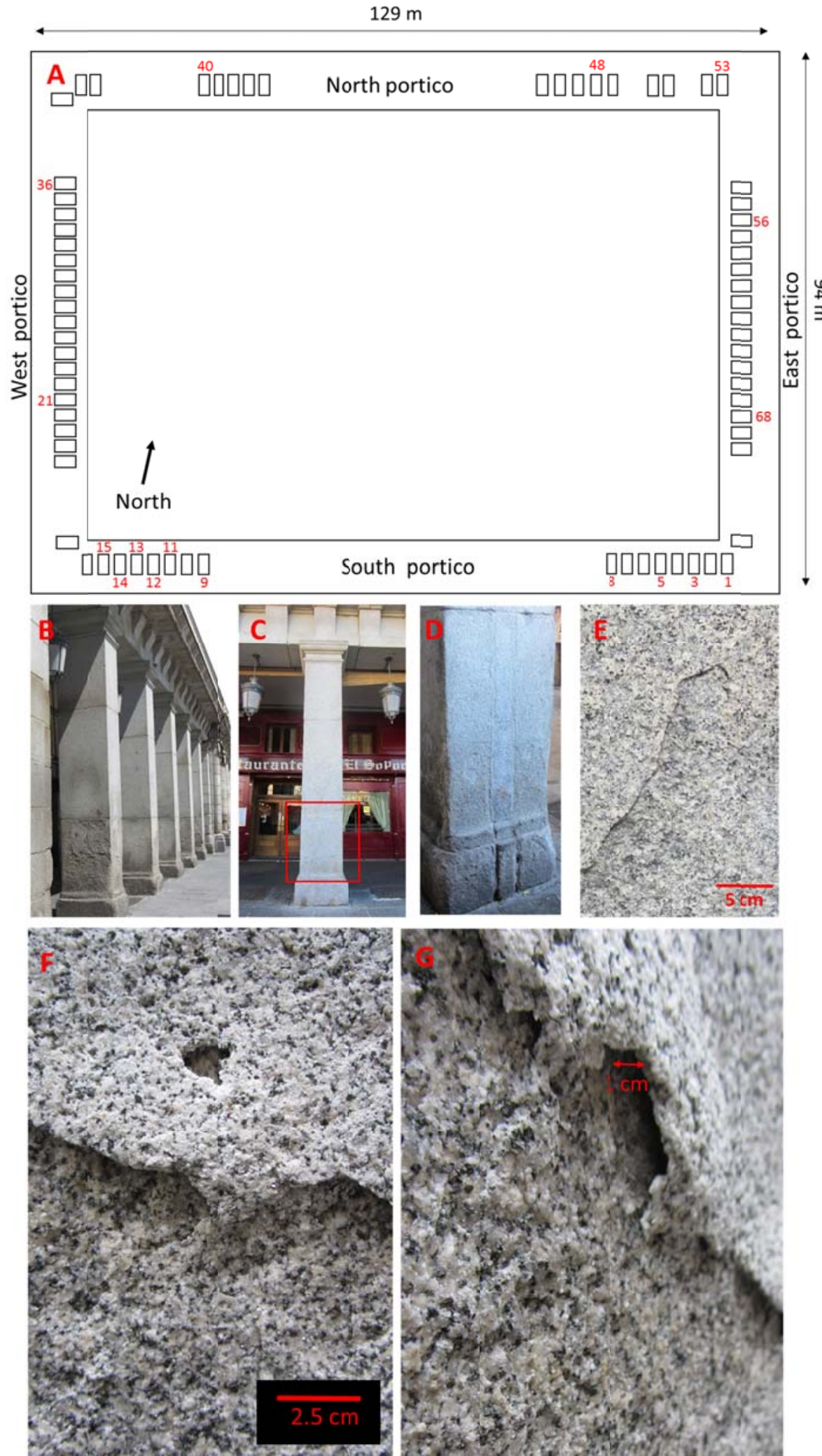
Figure 2. A: line drawing of Madrid's Plaza Mayor, showing the orthohedral columns on the inner side of the north, south, east and west porticos; B: columns in the north portico; C: column 62; D: column 1; E: scaling on column 48; F and G: details of scaling on column.

Three $30 \mu \mathrm{m}$ thick, $30 \times 20 \pm 3 \mathrm{~mm}$ thin sections were cut parallel to the cleft plane of the step at depths of 2, 10 and $30 \mathrm{~mm}$, and one section was removed from the hard-way plane (Figure 3B).

Sectioning was performed at $120 \mathrm{rpm}$ to prevent additional damage and the original orientation was labelled.

All thin sections were impregnated with fluoresceine (Silva et al., 1993, Chigira, 2001) and characterised under an Olympus BX 51 polarised light microscope (PM) fitted with DP 12coupled (6 V/2.5 $\AA$ ) Olympus digital micrography and Olympus DP-Soft software (version 3.2). Microcracks were characterised with the same equipment and set-up using an Olympus U-RF-T mercury lamp fluorescence microscope (FM).

Each mosaic comprised micrographs measuring approximately $7 \mathrm{~cm}^{2}$. The cross-Nicols micromosaics were used for mineral quantification, and the fluorescence mosaics to study microcracks.

The FM micromosaic was positioned over the PM micromosaic. A $10 \times 15 \mathrm{~mm}$ rectangle was then drawn on this superimposed image and divided into $25 \mathrm{~mm}^{2}$ squares, 6 in all. Microcracking was quantified by counting the total number of microcracks intersecting with the sides of these squares (a total linear distance of $85 \mathrm{~mm}$ ). Lastly, linear crack density (LCD) was calculated as the number of microcracks per millimetre (Sousa et al., 2005).

Six lines were drawn perpendicular to the exfoliation microcracks on the mosaic for the thin section taken from the hard-way plane. Linear microcrack density was found by counting the total number of microcracks that intersected with these lines at depths of $0-2.5,2.5-7.5,7.5-12.5$ and $12.5-17.5 \mathrm{~mm}$ from the bush-hammered surface. The FM measurements were used to determine the distance to the surface of the microcracks induced by bush-hammering.

Ultrasound velocity ( $\mathrm{Vp}$ ) was measured directly on the four sides (in two orthogonal directions) of 10 columns (shown in red in Figure 2A). The mean of four consecutive measurements on each side was used as the accepted value. Vp was read on a CNS Electronics PUNDIT analyser (precision: $\pm 0.1 \mu \mathrm{s}$ ) pursuant to Spanish and European standard UNE-EN 14579:2007. One- 
megahertz transducers (11.82 $\mathrm{mm}$ in diameter) were attached to the granite surface with Henkel Sichozell Kleister (a carboxymethyl cellulose) paste and water to enhance the transducer-stone contact.
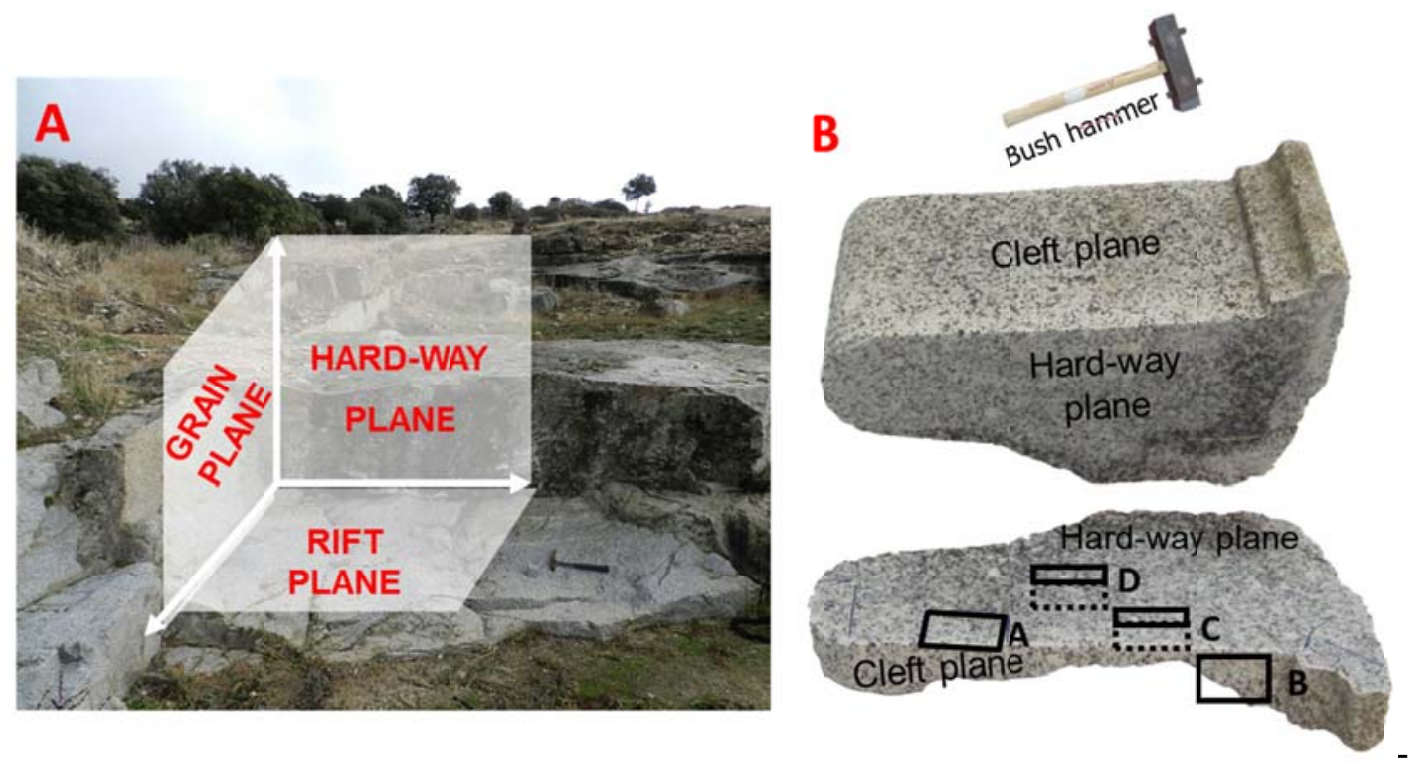

Figure 3. A: distribution of cutting planes in the historic quarry where the granite was mined; B: position of thin sections removed from the granite step found at the Alpedrete quarry.

\section{Results}

All the columns were built with the same type of stone, a medium-grained, hypidiomorphic, equigranular monzogranite, petrographically identical to the stair step from the Alpedrete quarry. The thin section analysed, which was removed from column 36 (Figure 4), exhibited straight transcrystalline microcracks parallel to the cleft plane.

Scaling was greatest in the columns on the square's north portico (Table 2). Nearly all (98\%) of the scaling was found on the bottom ashlars.

The narrow sides, i.e., the ones facing the square and the galleries, accounted for $30 \%$ of the scaling and the wider sides perpendicular to them for the remaining $70 \%$; the north portico columns were the ones most intensely scaled (Figure 2B). Scaling was mapped to be approximately 1-3 mm thick and to run parallel to the ashlar surface.

Table 1. Mean ultrasound transmission velocity (Vp) and standard deviation (measurements on 10 columns) 


\begin{tabular}{|c|c|c|}
\hline Column & $\begin{array}{c}\text { Vp (m/s) } \\
\perp_{\text {small area sides }}\end{array}$ & $\begin{array}{c}\text { Vp }(\mathbf{m} / \mathbf{s}) \\
\perp_{\text {large }} \text { area sides }\end{array}$ \\
\hline $\mathbf{1}$ & $2870 \pm 75$ & $3946=134$ \\
$\mathbf{3}$ & $3107 \pm 125$ & $2829=57$ \\
$\mathbf{5}$ & $2603 \pm 548$ & $3540=7$ \\
$\mathbf{8}$ & $4309 \pm 183$ & $3966=423$ \\
$\mathbf{9}$ & $3318 \pm 272$ & $2922=57$ \\
$\mathbf{1 1}$ & $4209 \pm 152$ & $3854=186$ \\
$\mathbf{1 2}$ & $3143 \pm 133$ & $2744=119$ \\
$\mathbf{1 3}$ & $3291 \pm 237$ & $2620=140$ \\
$\mathbf{1 4}$ & $4390 \pm 236$ & $3757=89$ \\
$\mathbf{1 5}$ & $4462 \pm 509$ & $3643=216$ \\
\hline
\end{tabular}

2

3

6 7

8 7 8
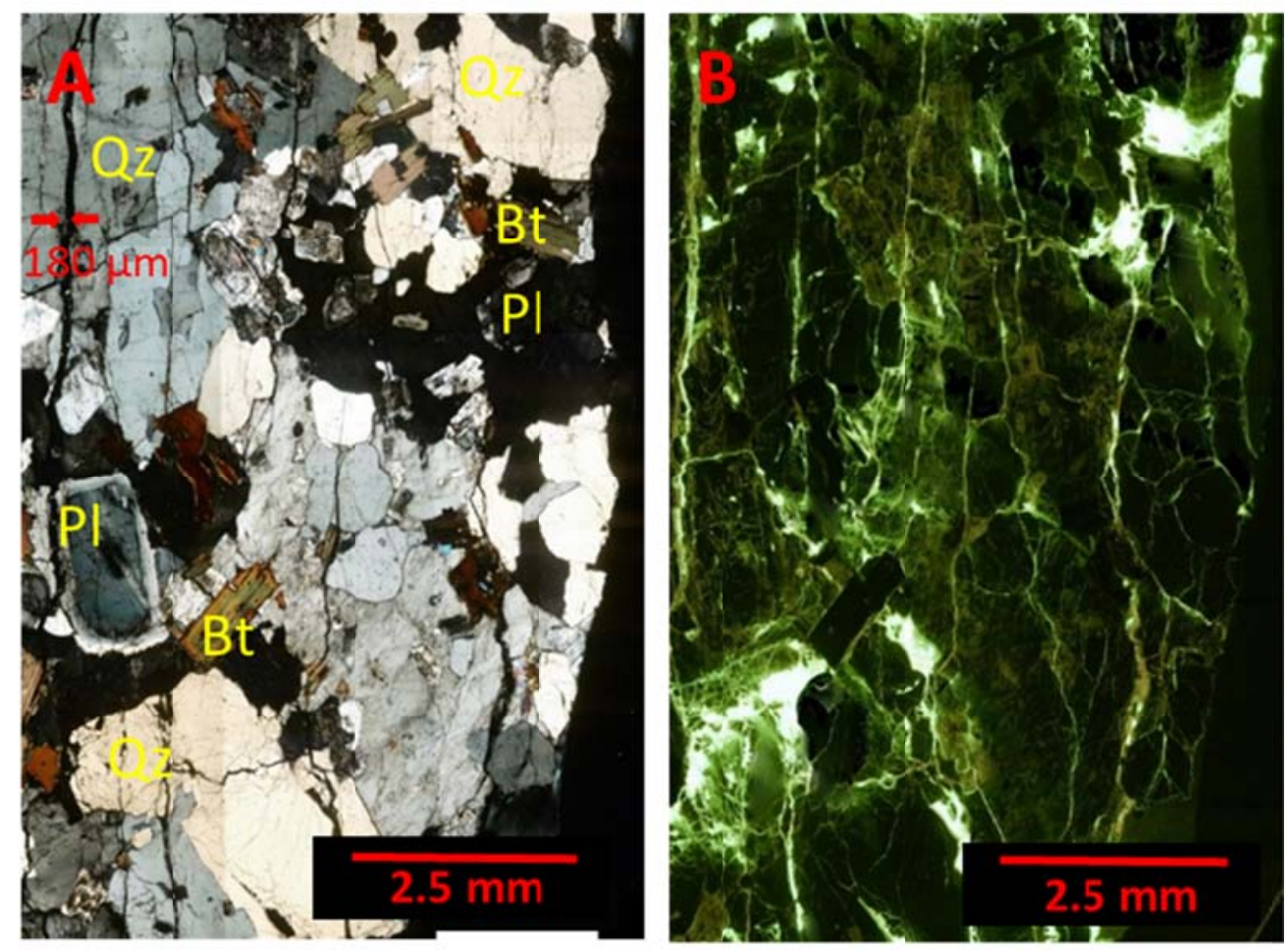

Figure 4. Thin section removed from column 36 perpendicular to the cleft plane (right side); A: cross-Nicol micrograph mosaic; B: fluorescence micrograph mosaic showing biotite (Bi), plagioclase $(\mathrm{Pl})$ and quartz $(\mathrm{Qz})$ affected by microcracking.

Table 2. Area affected by scaling on the columns in Madrid's Plaza Mayor 


\begin{tabular}{|c|c|c|}
\hline PORTICO & SIDE FACING & SCALING AREA (\%) \\
\hline \multirow{5}{*}{ South portico } & Exposed sides facing north & 8.8 \\
& Semi-exposed side facing east & 15.6 \\
& Protected side facing south & 7.2 \\
& Semi-exposed side facing west & 12.1 \\
\hline \multirow{5}{*}{ Nest portico } & Exposed sides facing east & 4.1 \\
& Semi-exposed side facing south & 6.3 \\
& Protected side facing west & 4.5 \\
& Semi-exposed side facing north & 5.5 \\
\hline & Exposed sides facing south & 15.0 \\
& Semi-exposed side facing west & 18.6 \\
& Protected side facing north & 7.4 \\
& Semi-exposed side facing east & 15.3 \\
\hline \multirow{5}{*}{ East portico } & Exposed sides facing west & 3.7 \\
& Semi-exposed side facing north & 6.4 \\
& Protected side facing east & 2.1 \\
& Semi-exposed side facing south & 5.9 \\
\hline
\end{tabular}

2

3

Figure 5A shows the micromosaic for the thin section removed from the hard-way plane on the Alpedrete stair step. LCD and crack spacing by distance from the surface are given in Table 3 for each half of the thin section. Two types of surface decay are visible in Figure 5A: crystal loss on the left and coalescence on the right. Coalescence was greater and exfoliation microcrack spacing narrower in the upper 2.5 millimetres from the bush-hammered surface (Table 3). A plane of weakness was observed at approximately $1 \mathrm{~mm}$ from the surface, generating an area of connectivity parallel to the cleft plane.

Figures 5B, 5C and 5D depict the thin sections taken along the cleft plane at various distances from the bush-hammered surface of the stair step. The crack count yielded LCDs of 1.7 microcracks per millimetre for the thin section taken at $2 \mathrm{~mm}$ from the bush-hammered surface, 0.7 for the sample sectioned at $10 \mathrm{~mm}$ and 0.5 for the one removed at $30 \mathrm{~mm}$. The number of microcracks intersecting with the lattice is given in Table 4 . 


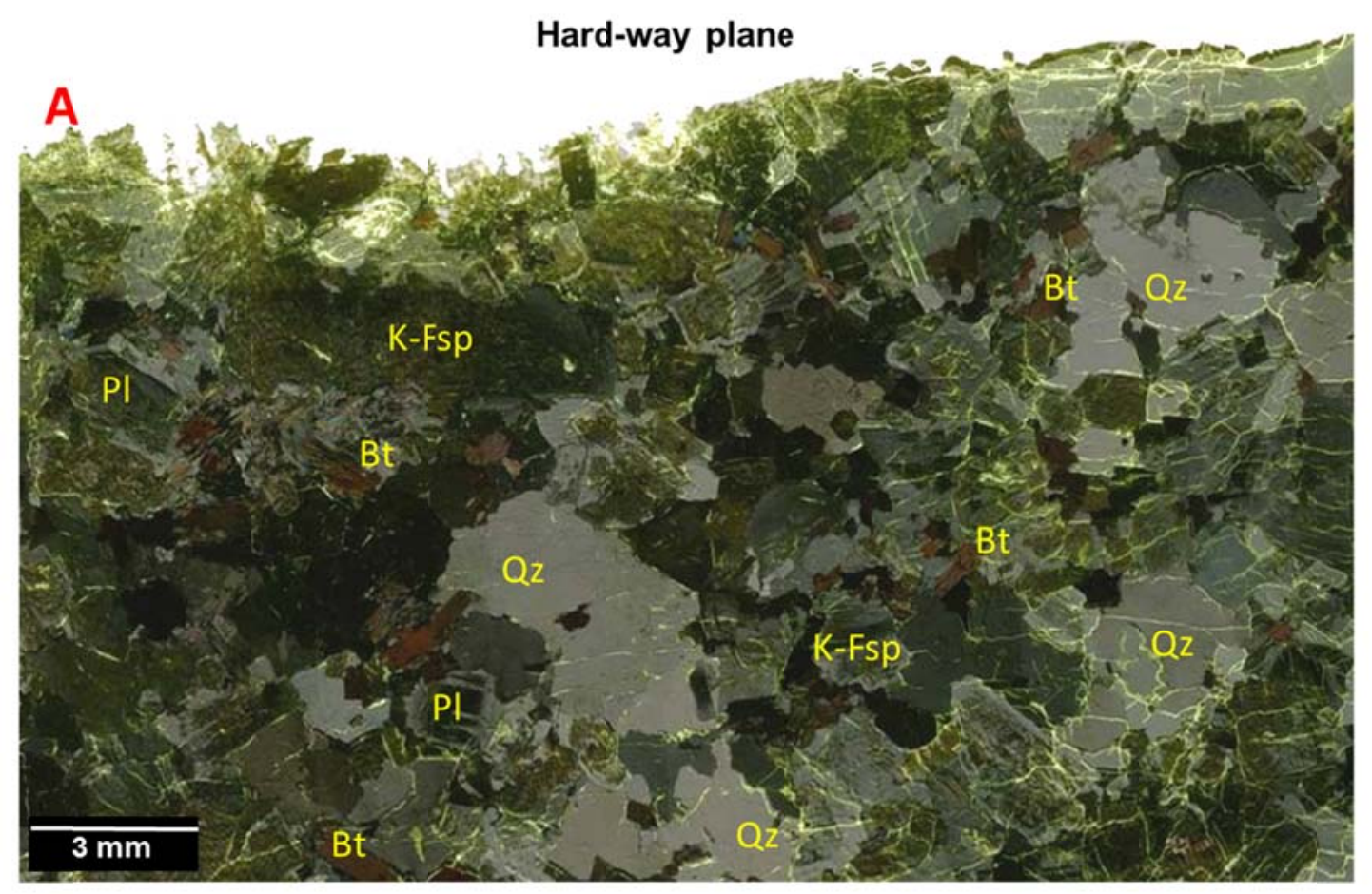

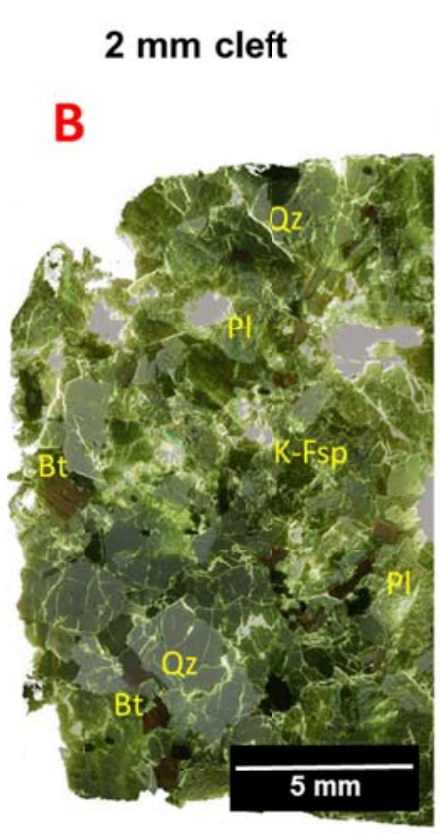

LCD = 1.7

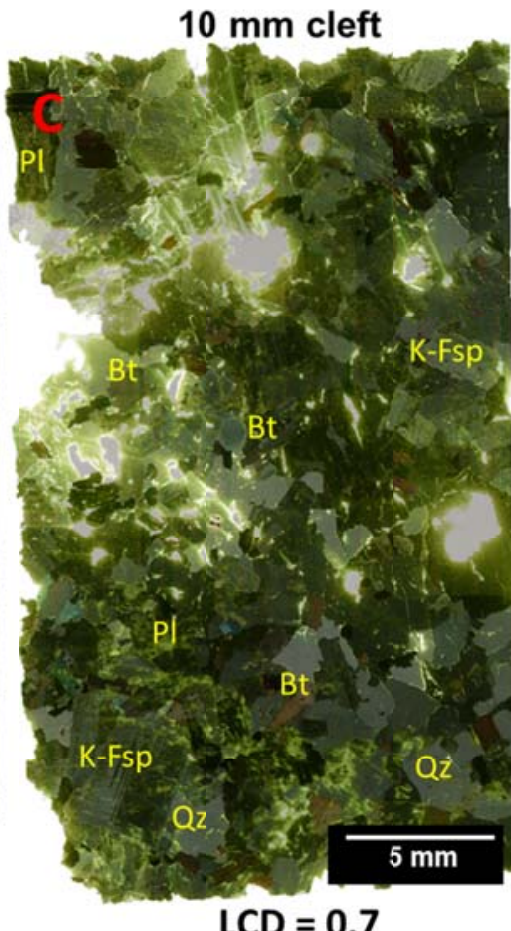

$\mathrm{LCD}=0.7$

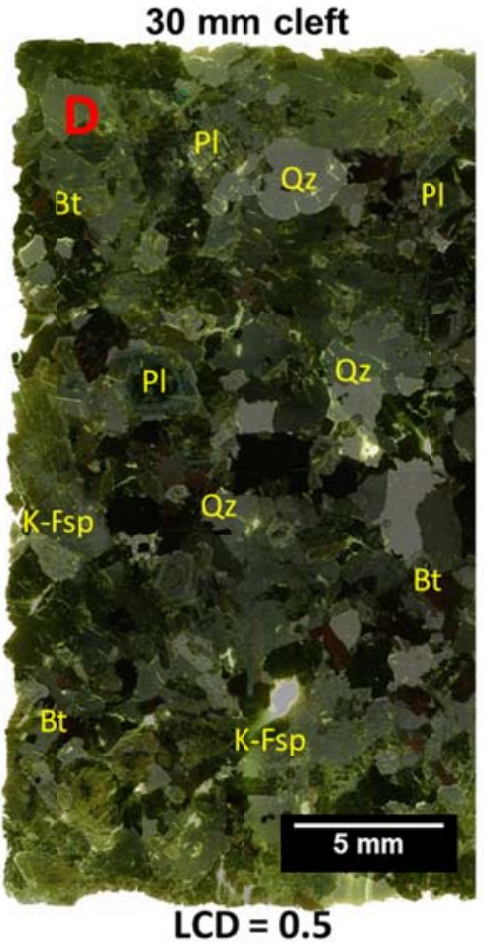

Figure 5. Fluorescence micrograph mosaic overlaid on polarised light micrograph mosaic showing biotite $(\mathrm{Bi})$; K-feldspar (K-Fsp), plagioclase (Pl) and quartz (Qz) affected by microcracking; A: FM micromosaic for thin section removed along the hard-way plane of a granite stair step; B, C and D: micromosaics for thin sections removed along the cleft plane of the same step at 2, 10 and $30 \mathrm{~mm}$ from the bush-hammered surface.

Table 3. Linear crack density (LCD) and mean spacing at different depths from the bushhammered surface (thin section cut along the hard-way plane). 


\begin{tabular}{|c|c|c|c|c|}
\hline \multirow{2}{*}{$\begin{array}{c}\text { Surface } \\
\text { depth (mm) }\end{array}$} & $\begin{array}{c}\text { LCD } \\
\text { (Microcraks } \\
\text { per mm) }\end{array}$ & $\begin{array}{c}\text { Microcracks } \\
\text { spacing }\end{array}$ & $\begin{array}{c}\text { LCD } \\
\text { (Microcraks } \\
\text { per mm) }\end{array}$ & $\begin{array}{c}\text { Microcracks } \\
\text { spacing }\end{array}$ \\
\hline $0-2.5$ & crystal lost & crystal lost & 2.5 & 0.4 \\
\hline $2.5-7.5$ & 0.6 & 1.7 & 1.5 & 0.6 \\
\hline $7.5-12.5$ & 0.6 & 1.7 & 1.2 & 0.8 \\
\hline $12.5-17.5$ & 0.6 & 1.7 & 0.6 & 1.7 \\
\hline
\end{tabular}

Table 4. Number of microcracks intersected by the lattice $(85 \mathrm{~mm}$, linear).

\begin{tabular}{|c|c|c|}
\hline $\begin{array}{c}\text { Depth from } \\
\text { surface (mm) }\end{array}$ & $\begin{array}{c}\text { Intracrystalline } \\
\text { microcracks }\end{array}$ & $\begin{array}{c}\text { Intercrystalline } \\
\text { microcracks }\end{array}$ \\
\hline 2 & 170 & 91 \\
10 & 106 & 78 \\
30 & 81 & 71 \\
\hline
\end{tabular}

\section{Discussion}

While a number of authors have put forward systems for classifying construction stone decay (Ordaz and Esbert, 1988; Fitzner and Heinrichs, 2002; ICOMOS, 2008), no broad consensus has yet been reached on standardised terminology. To use the ICOMOS nomenclature, the types of decay studied here would constitute blistering, defined as air-filled, raised hemispheres on the face of stone resulting from the detachment of an outer stone layer, scaling and spalling, a subcategory of scaling, would also be present, for the surfaces affected are flat. Thin layers of decay coering small areas are termed flaking. According to ICOMOS (2008), stone structure per se is unaffected by detachments. The exfoliation microcracks in the thin sections of the ashlars analysed were found to be intrinsic to the stone and to have propagated and coalesced with hewing.

Chigira (2001), studying exfoliation joints in granite from an approach similar to the one adopted here, observed that microcrack weathering affected the stability of a granite hillside. Scaling is associated with weathering (Bromblet et al., 1996), although hewing technique, usage, exfoliation microcracks and ashlar orientation are factors to be borne in mind when diagnosing scaling in granite. The forms of decay are not always indicative of the processes inducing them (Cooke and Warren, 1973). 
2 Studies such as conducted by Lin and Takashi (2008) showed that in granite the highest Vp

3 values are observed in the areas with least microcracking along the cutting planes. Those planes

4 would run parallel to the cleft plane. In this study, $80 \%$ of the highest Vp readings were

5 recorded for the directions parallel to the wide sides, an indication that they may constitute the

6 cleft plane. Columns 1 and 3 exhibited a lower $\mathrm{Vp}$ in the direction parallel to the that side. A

7 vertical raceway covered by replacement granite on the narrow side of column 1 (Figure 1D)

8 may have distorted the Vp reading, which would explain the anomaly.

9 Decay was most intense on the north portico columns, the ones traditionally subject to greatest use, with the installation, for instance, of boxes and stages for theatrical performances or openair markets that called for more aggressive pavement hosing at the end of the day. Moreover, as this portico once housed a bus stop (Figure 1D), the stone was exposed to the particles emitted by gasoline and gas-oil engines (Simão et al., 2006). All these uses favoured scaling. In contrast, war-induced damage is not representative, thanks to the measures adopted to mitigate the effects of the Spanish Civil War on the columns in the Plaza Mayor (Figure 1E).

Daily solar exposure is longest and daytime temperatures highest in this portico, where the daytime/night-time temperature contrast induces fluctuations in the height of the capillary waterfront, most intensely in the bottom-most metre of the structure. That may explain why the base ashlar accounts for $98 \%$ of the scaling on these columns. The main sources of moisture would, then, be a high groundwater table and pavement hosing. Others include rainfall, ponding and the humidity in the air. All these sources contribute to scaling. The concentration of most of the scaling at mid-height on the bottom ashlars is an indication that its cause is the rise and fall of the moisture front. Such decay is more accentuated when the water carries salts. The capillary absorption coefficient in Alpedrete granite ranges from 1.523 to $3.1983 \mathrm{gm}^{-2} \cdot \mathrm{s}^{-0.5}$ (Fort et al., 2011).

26 Vasconcelos et al. (2009) explained granite cracking on the grounds of its microstructure. They noted that the rift and foliation planes define rock anisotropy. The mapping and microscopic study of the Plaza Mayor granite revealed the impact of exfoliation microcracks and hewing on 
scaling in granite. The broadest sides of the columns, most of which concur with the cleft plane, exhibited the most intense scaling. These sides are semi-protected, i.e., less exposed to the elements than the sides facing the square.

In contrast, a lesser degree of scaling was observed on the narrower sides, despite their exposure. Artificially accelerated ageing and thermal shock studies (Freire-Lista et al., 2015e) indicate that pre-existing cracks play a significant role in granite decay.

Halsey et al. (1998) and Zhang et al. (2010) contended that scaling is due to temperature differences between the surface and the inside of the rock. The detection of scaling in nodules irrespective of orientation and therefore of the degree of solar radiation would stand as proof, however, that thermal shock is not the sole decay mechanism (Gómez-Heras et al, 2008, Gräf et al., 2013). Le Pera and Sorriso-Valvo (2000), studying weathering in Sila massif granite boulders, reported that decay was affected by their biotite content. In this study, exfoliation microcracking was less developed in biotite than in any of the other constituent minerals (Figures 4 and 5), which may be an indication that the size and orientation of biotite plays a significant role in the development of exfoliation microcracks.

Zhou (2005) proposed a model for crack growth in brittle rocks based on micro-mechanics. According to that author, one-way pressure on ashlars generated by hewing induces coalescence in the pre-existing exfoliation microcracks. Yin et al. (2014) later wielded similar arguments. The impact inherent in bush-hammering causes surface decay. Two types of surface decay are visible in Figure 5A. The crystal loss in the outermost millimetres on the left was induced by the impact waves of the bush hammer as they rebounded against a layer of potassium feldspar oriented parallel to the cleft plane. The exfoliation microcracks underneath this feldspar, with widths of approximately $50 \mu \mathrm{m}$, exhibit barely any coalescence. In other words, the potassium feldspar obstructs wave propagation, 'shielding' the area below. The coalescing exfoliation microcracks on the right in Figure 5A generate planes of weakness. This same type of microcracks, approximately $90 \mu \mathrm{m}$ thick, appeared in the outermost millimetre of the granite stair step, a depth that concurs with the thickness of the scaling mapped on the columns studied. 
1 At greater depths, the microcracks are spaced more widely and are no wider than approximately

$265 \mu \mathrm{m}$. The intracrystalline cracks in Figure 5A are straight and parallel, whereas the

3 intracrystalline cracks in Figures 5B and 5C are ramified and run in no prevalent direction. In

4 other words, bush-hammering generates exfoliation microcrack coalescence parallel to the cleft

5 plane and generates more microcracks running in several directions to a depth of at least $1 \mathrm{~cm}$.

6 Table 2 shows that bush-hammering generates intracrystalline cracks and furthers the

7 development of the intercrystalline sort. Hence, the intra/inter-crystalline microcrack ratio

8 declines as the distance from the hewn surface rises. Taken together, these microcracks result in

9 a heavily microcracked surface (Figure 5) to a depth of $1 \mathrm{~cm}$, where water and other agents of decay may readily penetrate. That accelerates scaling due to the existence of planes parallel to the surface with densely inter-connected exfoliation microcracks.

The exfoliation microcracks in the area underneath the potassium feldspar observed on the left half of the thin section taken from the staircase are no more than approximately $70 \mu \mathrm{m}$ wide (Figure 5A). In contrast, the microcracks on the thin section taken from an ashlar on Madrid's Plaza Mayor measured up to $180 \mu \mathrm{m}$ (Figure 4). This greater width can be attributed to the weathering inherent in an ashlar hewn over 200 years ago (Cuccuru et al., 2012). Water may accumulate in exfoliation microcrack planes, generating decay due to salt crystallisation (LópezArce et al., 2010, Momeni et al., 2015) or frost (Freire-Lista et al., 2015a), further favouring scaling. Multi-directional microcracking, in turn, induces grain segregation and loss of surface finish.

The diagram in Figure 6 shows a cross-section perpendicular to the cleft plane on a traditionally hammered ashlar. The bush-hammered surface exhibits scores of variously oriented microcracks (right). The area with high microcrack connectivity visible at a depth of approximately $1 \mathrm{~mm}$ from the surface would facilitate capillary ingress and the resulting decay, ultimately causing detachment of this plane and the concomitant scaling. The microcracks deeper into the ashlar exhibit coalescence. 

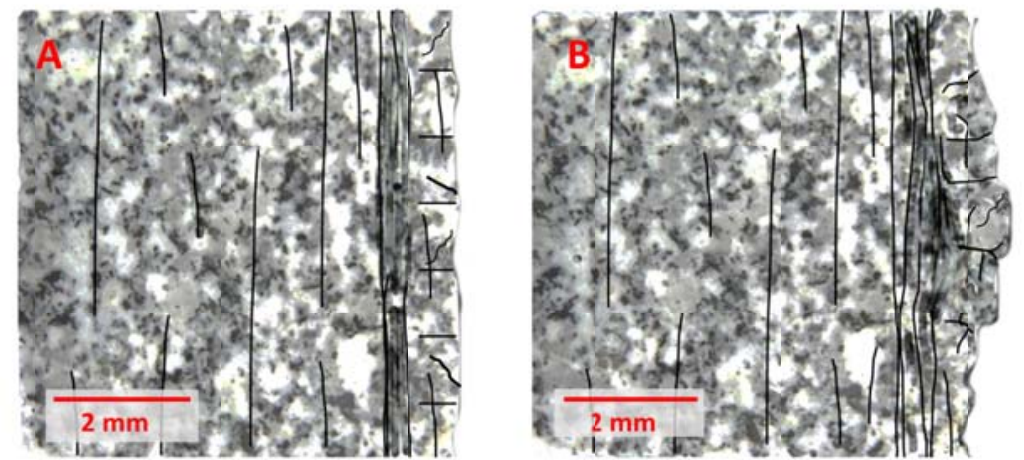

Figure 6. Scaling on a vertical cleft plane (profile): A, baseline condition of a bush-hammered granite ashlar; B, scaling with detachment at a depth of approximately $1 \mathrm{~mm}$ from the bushhammered surface.

\section{Conclusions}

Information on the anisotropic planes along which heritage stone was hewn and how it was laid relative to its exfoliation microcracks is essential when characterising granite decay, for these factors determine capillarity.

Traditional bush-hammering causes coalescence in existing microcracks and creates new ones.

The result is a plane with high connectivity located at approximately $1 \mathrm{~mm}$ from the outer surface. This circumstance favours the appearance of capillarity and salt and ice crystallisation, among other agents of decay. Moreover, bush-hammering generates a highly microcracked surface vulnerable to scaling, a frequent type of decay in heritage ashlars.

The broadest sides of the ashlars on Madrid's Plaza Mayor were laid in the general direction of the exfoliation microcracks, which consequently run perpendicular to the ground.

Ultrasound analysis identified the direction of the exfoliation microcracks. Decay was observed to be most accentuated on the north portico where usage has been historically most intense. Moreover, its south-facing columns are the ones most exposed to solar radiation. Capillary water rising along the exfoliation microcrack plane is a significant decay factor. Positioning hewn ashlars most suitably relative to that plane is, therefore, instrumental to preventing further decay.

The cause of scaling in granite may also induce such decay in other types of rocks with welldefined slip planes. 
1 The direction of exfoliation microcracks should be taken into consideration when applying

2 conservation treatments on sculptures or ashlars. The surface parallel to such microcracks, the

3 one most vulnerable to decay, is where treatments penetrate least deeply due to the low

4 capillarity in the perpendicular direction. Conversely, the surface perpendicular to the

5 microcracks is the one least vulnerable and most permeable to conservation treatments.

6

\section{Acknowledgements}

This study was funded by the Community of Madrid under the GEOMATERIALS (S2009/MAT-1629) and GEOMATERIALS-2CM (S2013/MIT-2914) research programmes and project 921349 awarded to the Complutense University of Madrid's Research Group 'Alteración y Conservación de los Materiales Pétreos del Patrimonio', of which the authors are members. Manuscript edited by Margaret Clark, professional translator and English language science editor.

\section{References}

Åkesson U, Hansson J, Stigha J (2004) Characterisation of microcracks in the Bohus granite, western Sweden, caused by uniaxial cyclic loading. Engineering Geology 72:131-142.

Alcalde Moreno M, Villegas Sánchez R (2003) Indicadores de alteración de los materiales pétreos. In: R. Villegas Sánchez y E.M. Sebastián Pardo (Editors), Metodología de diagnóstico y evaluación de tratamientos para la conservación de los edificios históricos. Comares, Granada, pp.58-71.

Alonso FJ, Vázquez P, Esbert RM, Ordaz J (2007) Influence of measuring conditions on roughness parameters of ornamental rocks. Workshop: Preservation of Natural Stone and Rock Weathering, Taylor \& Francis 13-16.

Alonso FJ, Vázquez P, Esbert RM, Ordaz J (2008) Durabilidad de granitos ornamentales: valoración de los daños inducidos por el ensayo de cristalización de sales. Materiales de Construcción 58:191-201.

Alves C, Sequeira Braga MA, Hammeker C (1996) Water transfer and decay of granitic stones in monuments. Surface Geosciences 397-402.

Anders MH, Laubach SE, Scholz, CH (2014) Microfractures: A review. Journal of Structural Geology 69:377-394.

Andrés de Pablo N, Palacios D (2004) Interrelación nieve/geomorfología en la Sierra de Guadarrama: altas cuencas del Ventisquero de La Condesa y Vademartín 30:85-116. 
Bahat D, Grossenbacher K, Karasaki K (1999) Mechanism of exfoliation joint formation in granitic rocks, Yosemite National Park. Journal of Structural Geology 21:85-96.

Begonha A, Braga MAS (2002) Weathering of the Oporto granite: geotechnical and physical properties. Catena 49:57-76.

Benavente D, García del Cura MA, Fort R, Ordoñez S (2004) Durability estimation of porous building stones from pore structure and strength. Engineering Geology 74:113-127.

Benavente D, Cultrone G, Gómez-Heras M (2008) The combined influence of mineralogical, hydric and thermal properties on the durability of porous building stones - European Journal of Mineralogy 20:673-685.

Benkó Z, Molnár F, Lespinasse M, Váczi T (2014) Evidence for exhumation of a granite intrusion in a regional extensional stress regime based on coupled microstructural and fluid inclusion plane studies-An example from the Velence Mts., Hungary. Journal of Structural Geology 65:44-58.

Brimblecombe P (2003) The effects of air pollution on the built environment. Imperial College Press. Peter Brimblecombe (Ed.):428 pp.

Brimblecombe P, Sturges K (2009) History of atmospheric environment. Atmospheric Environment 43 (1):2-8.

Bromblet P, Bernabé E, Vergès-Belmin V (1996) Petrophysical investigation on the origin of scaling of a microgranular magmatic rock associated to granite in the monuments from Brittany (France) - Environmental Protection and Conservation of the European Cultural Heritage Degradation and Conservation of Granitic Rocks, European Commission pp. 73-78.

Camuffo D (1995) Physical weathering of stones. The Science of the Total Environment 167:114.

Camuffo D (1998) Microclimate for Cultural Heritage. Elsevier Science; Developments in Atmospheric Science 26:428 pp.

Catlos E, Baker C, Sorensen S, Jacob L, Çemen I (2011) Linking microcracks and mineral zoning of detachment-exhumed granites to their tectonomagmatic history: Evidence from the Salihli and Turgutlu plutons in western Turkey (Menderes Massif). Journal of Structural Geology 33:951-969.

Chabas A, Jeannette D (2001) Weathering of marbles and granites in marine environment: petrophysical properties and special role of atmospheric salts - Environmental Geology 40 (3):359-368.

Chigira M (2001) Micro-sheeting of granite and its relationship with landsliding specifically after the heavy rainstorm in June 1999, Hiroshima Prefecture, Japan. Engineering Geology 59:219-231.

Cooke RU, Warren A (1973) Geomorphology in deserts. Batsford, London.

Coussy O, Fen-Chong T (2005) Crystallization, pore relaxation and micro-cryosuction in cohesive porous materials. Comptes Rendus Mécanique 333 (6):507-512. 
Cuccuru S, Casini L, Oggiano G, Cherchi GP (2012) Can weathering improve the toughness of a fractured rock? A case study using the San Giacomo granite. Bulletin of Engineering Geology and the Environment. 71:557-567.

Eberhardt E, Stimpson B, Stead D (1999) Effects of grain size on the initiation and propagation thresholds of stress induced brittle fractures - Rock Mechanics and Rock Engineering 32:81-99.

Erguler ZA (2009) Field-based experimental determination of the weathering rates of the Cappadocian tuffs. Engineering Geology 105:186-199.

Erguler ZA, Shakoor A (2009) Relative contribution of various climatic processes in disintegration of clay-bearing rocks. Engineering Geology 108:36-42.

Esbert Alemany RM (2007) Alteration of granite stone used in building construction. Materiales de Construcción 57:288, 77-89.

Fitzner B, Heinrichs K (2002) Damage diagnosis on stone monuments - weathering forms, damage categories and damage indices. In: R. Prikryl and H.A. Viles (Editores), Understanding and Managing Stone Decay, Proceedings of the International Conference Stone Weathering and Atmospheric Pollution Network (SWAPNET). Karolinum Press, Prague, pp. 11-56.

Fort R, Varas MJ, Alvarez de Buergo, M, Martin-Freire, D (2011) Determination of anisotropy to enhance the durability of natural stone. Journal of Geophysics and Engineering 8:132-144. doi:10.1088/1742-2132/8/3/S13.

Fort R, Alvarez de Buergo M, Perez-Monserrat EM, Gomez-Heras M, Varas-Muriel MJ, Freire D. (2013) Evolution in the use of natural building stone in Madrid, Spain. Quarterly Journal of Engineering Geology and Hydrogeology 46:421-429.

Freire-Lista DM, Fort R, Varas-Muriel MJ (2015a) Freeze-thaw fracturing in building granites. Cold Regions Science and Technology 113:40-51. Doi: 10.1016/j.coldregions.2015.01.008.

Freire-Lista DM, Gomez-Villalba LS., Fort R (2015b) Microcracking of granite feldspar during thermal artificial processes. Periodico di mineralogia 84 (3A):519-537.

Freire-Lista DM, Fort R (2015c) The Piedra Berroqueña region: candidacy for Global Heritage Stone Province status. Geoscience Canada https://journals.lib.unb.ca/index.php/GC/issue/view/1603

Freire-Lista DM, Fort R, Varas-Muriel MJ (2015d) Alpedrete granite (Spain). A nomination for the "Global Heritage Stone Resource" designation. Episodes 38 (2):1-8.

Freire-Lista DM, Fort R, Varas-Muriel MJ (2015e) Thermal effects-induced microcracking in building granite. Engineering Geology (In review)

Fujii Y, Takahashi M, Hori S (2007) Three-dimensional topography of fracture surfaces obtained by a digital photogrammetric technique. International Journal of the JCRM. 3 (1):3136.

Gräf V, Jamek M, Rohatsch A, Tschegg E (2013) Effects of thermal-heating cycle treatment on thermal expansion behavior of different building stones. Rock Mechanics \& Mining Sciences, 64:228-235. 
García-del-Cura, MA, Benavente D, Bernabéu A, Martínez-Martínez J (2008) The effect of surface finishes on outdoor granite and limestone pavers. Materiales de Construcción 58 (289290):65-79.

Gómez-Heras M, Smith BJ, Fort R, (2006) Surface temperature differences between minerals in crystalline rocks: implications for granular disaggregation of granites through thermal fatigue. Geomorphology 78 (3-4):236-249.

Gómez-Heras M, Smith BJ, Fort R (2008) Influence of surface heterogeneities of building granite on its thermal response and its potential for the generation of thermoclasty. Environmental Geology 56:547-560.

Gómez-Heras M, Mccabe S, Smith BJ, Fort R (2009) Impacts of Fire on Stone-Built Heritage: An Overview. International Journal of Architectural Heritage 2 (15):47-59.

Grossi CM, Esbert RM, Díaz-Pache F (1998) Decay and durability of building stones in urban environments. Degradación y durabilidad de materiales rocosos de edificación en ambientes urbanos 252:5-25.

Gupta AS, Seshagiri Rao K (1998) Index properties of weathered rocks: interrelationship and applicability. Bulletin of Engineering Geology and the Environment 57:161-172.

Hall K (1999) The role of thermal stress fatigue in the breakdown of rock in cold regions. Geomorphology 31:47-63.

Hall K, Thorn E, Sumner P (2012) On the persistence of 'weathering' Geomorphology 149150:1-10.

Hall K, Thorn E, (2014) Thermal fatigue and thermal shock in bedrock: An attempt to unravel the geomorphic processes and products. Geomorphology 206:1-13.

Halsey DP, Mitchell DJ, Dews SJ (1998) Influence of climatically induced cycles in physical weathering Quarterly Journal of Engineering Geology 31:359-367.

Hamdi E, Romdhane NB, du Mouza J, Le Cléac'h, JM (2008) Fragmentation energy in rock blasting. Geotechnical and Geological Engineering 26:133-146.

Hamdi E, Romdhane NB, Le Cléac'h, JM (2011) A tensile damage model for rocks: application to blast induced damage assessment. Computers and Geotechnics 38:133-141.

Hamdi E, Lafhaj Z, (2013) Microcracking based rock classification using ultrasonic and porosity parameters and multivariate analysis methods. Engineering Geology 167:27-36.

Hoffmann D, Niesel K (1992) Pore structure of rendering as a feature of its weathering - 7th International Congress on the Deterioration and Conservation of Stone, Lisbon, 611-620.

Holzhausen GR (1989) Origin of sheet structure, 1. Morphology and boundary conditions. Engineering Geology 27:225-278.

Hor M, Morihiro H (1998) Micromechanical analysis on deterioration due to freezing and thawing in porous brittle materials. International Journal of Engineering Science 36 (4):511522 . 
Jo VH, Lee CH (2014) Quantitative modeling and mapping of blistering zone of the Magoksa Temple stone pagoda (13th century, Republic of Korea) by graduated heating thermography. Infrared Physics \& Technology 65:43-50.

Laubach SE, Olson JE, Gale JFW (2004) Are open fractures necessarily aligned with maximum horizontal stress. Earth and Planetary Science Letters 222:191-195.

Le Pera E, Sorriso-Valvo M (2000) Weathering and morphogenesis in a mediterranean climate, Calabria, Italy. Geomorphology 34:251-270.

Lin W (2002) Permanent strain of thermal expansion and thermally induced microcracking in Inada granite. Journal of geophysical research 107(B10):1-16.

Lin W, Takahashi M (2008) Anisotropy of strength and deformation of Inada granite under uniaxial tension. Chinese Journal of Rock Mechanics and Engineering 27 (12):2463-2472.

Lindqvist JE, Akesson U, Malaga K (2007a) Microstructure and functional properties of rock materials. Materials Characterization 58:1183-1188.

Lindqvist JE, Malaga K, Middendorf B, Savukoski M, Pétursson P (2007b) Frost resistance of natural stone, the importance of micro- and nano-porosity - online: http://www.sgu.se/dokument/fou_extern/Lindqvist-et-al_2007.pdf

López-Arce P, Varas-Muriel MJ, Fernández-Revuelta B, Álvarez de Buergo M, Fort R, PérezSoba C (2010) Durability of granites from the region around Madrid, Spain, exposed to the salt crystallization test: intra- and inter-granular surface roughness quantification. Catena 83 (23):170-185.

López-Arce P, Fort R, Gómez-Heras M, Perez-Monserrat E, Varas, MJ (2011) Preservation strategies for avoidance of salt crystallisation in El Paular Monastery cloister, Madrid, Spain. Environmental Earth Sciences 63:1487-1509.

ICOMOS-ISCS (2008) International Scientific Committee for Stone (ISCS). Comité scientifique international "Pierre" de l'ICOMOS. Illustrated glossary on stone deterioration patterns ISBN: 978-2-918086-00-0 EAN: 9782918086000.

Jeannette D (1997) Importance of the pore structures during the weathering process of stones in monuments - In. Soils and Sediments, Mineralogy and Geochemistry; Paquet, H., Clauer, N., Eds.; Springer: Berlin, Germany, 177-190.

Koch A, Siegesmund S (2004) The combined effect of moisture and temperature on the anomalous expansion behaviour of marble. Environmental Geology 46:350-363.

Martínez-Martínez J, Benavente D, García del Cura MA (2006) La propagación de ultrasonidos en el estudio de materiales pétreos: Aplicación al estudio de las propiedades textoestructurales de las rocas y de su grado de alteración. Ingenieria del Terreno. Ingeoter, 8. Ed. Carlos López Jimeno, $440 \mathrm{pp}$.

Matías JMS, Alves CAS (2002) The influence of petrographic, architectural and environmental factors in decay patterns and durability of granite stones in Braga monuments (NW Portugal). Natural Stone, Weathering Phenomena, Conservation Strategies and Case Studies. Ed. Siegesmund S, Weiss T, Vollbrecht A, Geological Society, London, Special Publications 205:273-281. 
Moses C, Robinson D, Barlow J (2014) Methods for measuring rock surface weathering and erosion: A critical review. Earth-Science Reviews 135:141-161.

Momeni A, Khanlari GR, Heidari M, Bagheri R. Bazvand E (2015) Assessment of physical weathering effects on granitic ancient monuments, Hamedan, Iran. Environmental Earth Sciences 74:5181-5190.

Nadan BJ, Engelder T (2009) Microcracks in New England granitoids: a record of thermoelastic relaxation during exhumation of intracontinental crust. Geological Society of America Bulletin 121:80-99.

Nováková L, Sosna K, Brož M, Najser J, Novák P (2011) Geomechanical parametres of the Podlesí granites and their relationship to seismic velocities. Acta Geodyn. Geomater 8:3 (163), 353-369.

Ordaz J, Esbert RM (1988) Glosario de términos relacionados con el deterioro de las piedras de construcción Materiales de Construcción 38 (209):39-45.

Pérez-Ortiz A, Ordaz J, Esbert RM, Alonso FJ, Díaz Pache F (1996) Physical behavior and degradation trends in an anisotropic granite. 8th International Congress on deterioration and conservation stone, Berlin I:305-309.

Pires V, Rosa LG, Dionísio A (2014) Implications of exposure to high temperatures for stone cladding requirements of three Portuguese granites regarding the use of dowelhole anchoring systems. Construction and Building Materials 201 (64):440-450.

Přikryl R (2001) Some microstructural aspects of strength variations in rocks. International Journal of Rock Mechanics and Mining Sciences 38:671-82.

Přikryl R, Lokajıček T, Li C, Rudajev V (2003) Acoustic emission characteristics and failure of uniaxially stressed granitic rocks: the effect of rock fabric. Rock Mechanics and Rock Engineering 36 (4):255-270.

Rivas T, Pozo S, Fiorucci MP, López AJ, Ramil A (2012) Nd:YVO4 laser removal of graffiti from granite. Influence of paint and rock properties on cleaning efficacy. Applied Surface Science 263:563-572.

Rodríguez-Navarro C, Doehne E, Sebastian E (2000) Influencing crystallization damage in porous materials through the use of surfactants: experimental results using sodium dodecyl sulfate and cetyldimethylbenzylammo-nium chloride. Langmuir 16:947-954.

Schiavon N (2000) Granitic building stone decay in an urban environment: a case of authigenic kaolinite formation by heterogeneous sulphur dioxide attack. 9th International Congress on Deterioration and Conservation of Stone, (Venice 19-24):411-421.

Shadmon A (1989) Stone: An Introduction. ITDG Publishing.

Silva B, Rivas T, Prieto B, Martinez A (1993) Methodology for the study of weathering of granitic building Stone. Cuaderno Laboratorio Xeolóxico de Laxe 18:345-354.

Siegesmund S, Weiss T, Vollbrecht A (eds.) (2002) Natural Stone, Weathering Phenomena, Conservation Strategies and Case Studies - Geological Society Special Publication No. 25 London. 
Siegesmund S, Török A (2011) Building stones. In: Siegesmund, S., Snethlage, R. (eds) Stone in architecture-properties, durability, $4^{\circ}$ edit. Springer, Berlin, 11-96.

Siegesmund S, Snethlage R (eds.) (2014) Stone in Architecture, $5^{\circ}$ edit. 2014, XIII:550 pp. DOI 10.1007/978-3-642-45155-3.

Simão J, Ruiz-Agudo E, Rodríguez-Navarro C (2006): Effects of particulate matter from gasolina and diesel vehicle exhaust emission on silicate stone sulfation - Atmospheric Environment 40:6905-6917.

Sinha S, Alsop GI, Biswal TK (2010) The evolution and significance of microfracturing within feldspars in low-grade granitic mylonites: A case study from the Eastern Ghats Mobile Belt, India. Journal of Structural Geology 32:1417-1429.

Sousa LMO, Suárez del Río LM, Calleja L, Ruiz de Argandoña VG, Rodríguez Rey A (2005) Influence of microfractures and porosity on the physico-mechanical properties and weathering of ornamental granites. Engineering Geology 77:153-168.

Sousa LMO (2010) Evaluation of joints in granitic outcrops for dimension stone exploitation. Bulletin of Engineering Geology and the Environment 42:85-94.

Sousa LMO (2013) The influence of the characteristics of quartz and mineral deterioration on the strength of granitic dimensional stones. Environmental Earth Sciences 69 (4):1333-1346.

Sousa LMO, Gonçalves BMM (2013) Differences in the quality of polishing between sound and weathered granites. Environmental Earth Sciences 69 (4):1347-1359.

Takarli M, Prince-Agbodjan W (2008) Temperature Effects on Physical Properties and Mechanical Behavior of Granite: Experimental Investigation of Material Damage. Journal of ASTM international 5 (3):1-13.

Takarli M, Prince W, Siddique R (2008) Damage in granite under heating/cooling cycles and water freeze-thaw condition. International Journal of Rock Mechanics \& Mining Sciences, 45:1164-1175.

Takemura T, Golshani A, Oda M, Suzuki K (2003) Preferred orientations of open microcracks in granite and their relation with anisotropic elasticity. International Journal of Rock Mechanics and Mining Sciences 40:443-454.

Török A, Rozgonyi N (2004) Morphology and mineralogy of weathering crusts on highly porous oolitic limestones, a case study from Budapest. Environmental Geology 46:333-349.

Turkington AV (2002) Perception and prediction of stone durability - In: Annual Meeting of Decay and Conservation of Stone Buildings and Monuments, Denver Paper, 37-6.

Upadhyay D (2012) Alteration of plagioclase to nepheline in the Khariar alkaline complex, SE India: Constraints on metasomatic replacement reaction mechanisms. Lithos 155:19-29.

Vandevoorde D, Pamplona M, Schalm O, Vanhellemont Y, Cnudde V, Verhaeven E (2009) Contact sponge method: Performance of a promising tool for measuring the initial water absorption. Journal of Cultural Heritage 10 (1):41-47.

Varas-Muriel MJ, Fort R, Martínez-Garrido MI, Zornoza-Indart A, López-Arce P (2014) Fluctuations in the indoor environment in Spanish rural churches and their effects on heritage 
conservation: hygro-thermal and $\mathrm{CO} 2$ conditions monitoring. Building and Environment 82:97109.

Varas-Muriel MJ, Pérez-Monserrat EM, Vázquez-Calvo C, Fort R (2015) Effect of conservation treatments on heritage stone. Characterization of decay processes in a case study. Construction and Building Materials 95:611-622.

Vasconcelos G, Laurenço PB, Alves CSA, Pamplona J (2007) Prediction of the mechanical properties of granites by ultrasonic pulse velocity and Schmidt Hammer hardness. Proc. 10th North American Masonary Conference, St Louis, Missouri, pp. 980-991.

Vasconcelos G, Lourenço PB, Alves CAS, Pamplona J (2009) Compressive Behavior of Granite: Experimental Approach. Journal of Materials in Civil Engineering 21(9):502-511.

Vázquez-Menéndez P, Esbert RM, Alonso FJ, Ordaz J (2008) Evaluation of damage induced by salt crystallization in granitic building stones. 11th International congress on Deterioration and Conservation of Stone, Torún. Eds. Jadwiga W. Lukaszewicz y Piotr Niemcewicz, I:325-332.

Vázquez P, Shushakova V, Gómez-Heras M (2015) Influence of mineralogy on granite decay induced by temperature increase: Experimental observations and stress simulation. Engineering Geology 189:58-67.

Wilson MJ (2004) Weathering of the primary rock-forming minerals: processes, products and rates. Clay Minerals 39:233-266.

Weiss T, Siegesmund S, Rosolofosaon P (2000) The relationship between deterioration, fabric, velocity and porosity constraint. $9^{\circ}$ Congreso internacional de deterioro y conservación de rocas, Fassina V, (ed.) 1:215-223.

Yin P, Wong Chau KT (2014) Coalescence of two parallel pre-existing surface cracks in granite. International Journal of Rock Mechanics \& Sciences 686:6-84.

Yu S, Oguchi CT (2010) Role of pore size distribution in salt uptake, damage, and predicting salt susceptibility of eight types of Japanese building stones. Engineering Geology 115:226-236.

Zhang P, Nordlund E, Mainali G, Saiang C, Jansson R, Adl-Zarrabi B (2010) Experimental study on thermal spalling of rock blocks exposed to fire. Bergmekanikk i Norden $2010=$ Rock mechanics in the Nordic countries. 294-305

Zhou XP (2005) Localization of deformation and stress-strain relation for mesoscopic heterogeneous brittle rock materials under unloading. Theoretical and Applied Fracture Mechanics 44:27-43.

Ziegler M, Loew S, Moore JR (2013) Distribution and inferred age of exfoliation joints in the Aar Granite of the central Swiss Alps and relationship to Quaternary landscape evolution. Geomorphology 201:344-362.

Ziegler M, Loew S, Bahat D (2014) Growth of exfoliation joints and near-surface stress orientations inferred from fractographic markings observed in the upper Aar valley (Swiss Alps). Tectonophysics 626:1-20. 